\title{
A device for extraction, manipulation and stretching of DNA from single human chromosomes
}

Rasmussen, Kristian Hagsted; Marie, Rodolphe; Moresco, Jacob Lange; Svendsen, Winnie Edith; Kristensen, Anders; Mir, Kalim U.

\author{
Published in: \\ Lab on a Chip
}

Link to article, DOI:

$10.1039 / \mathrm{c} 0 \mathrm{lc} 00603 \mathrm{c}$

Publication date:

2011

Document Version

Publisher's PDF, also known as Version of record

Link back to DTU Orbit

Citation (APA):

Rasmussen, K. H., Marie, R., Moresco, J. L., Svendsen, W. E., Kristensen, A., \& Mir, K. U. (2011). A device for extraction, manipulation and stretching of DNA from single human chromosomes. Lab on a Chip, 11(8), 14311433. https://doi.org/10.1039/c0lc00603c

\section{General rights}

Copyright and moral rights for the publications made accessible in the public portal are retained by the authors and/or other copyright owners and it is a condition of accessing publications that users recognise and abide by the legal requirements associated with these rights.

- Users may download and print one copy of any publication from the public portal for the purpose of private study or research.

- You may not further distribute the material or use it for any profit-making activity or commercial gain

- You may freely distribute the URL identifying the publication in the public portal 

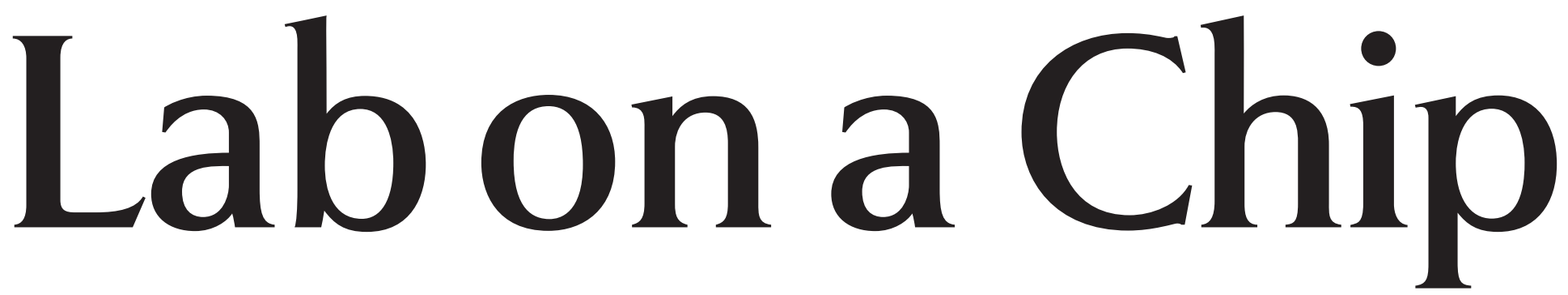

Micro- \& nano- fluidic research for chemistry, physics, biology, \& bioengineering 


\title{
A device for extraction, manipulation and stretching of DNA from single human chromosomes $\dagger$
}

\author{
Kristian H. Rasmussen, ${ }^{a}$ Rodolphe Marie, ${ }^{* a}$ Jacob M. Lange, ${ }^{a}$ Winnie E. Svendsen, ${ }^{a}$ Anders Kristensen ${ }^{a}$ \\ and Kalim U. Mir ${ }^{b}$
}

Received 15th November 2010, Accepted 1st February 2011

DOI: 10.1039/c0lc00603c

We describe the structure and operation of a micro/nanofluidic device in which individual metaphase chromosomes can be isolated and processed without being displaced during exchange of reagents. The change in chromosome morphology as a result of introducing protease into the device was observed by time-lapse imaging; pressure-driven flow was then used to shunt the chromosomal DNA package into a nanoslit. A long linear DNA strand (>1.3 Mbp) was seen to stretch out from the DNA package and along the length of the nanoslit. Delivery of DNA in its native metaphase chromosome package as well as the microfluidic environment prevented DNA from shearing and will be important for preparing ultra-long lengths of DNA for nanofluidic analysis.

The ability to extract, handle and visualize DNA from each individual chromosome (from the human set of 46, for example) would enable the native long-range organization of diploid genomes and the variation between chromosomes within (i.e. homologs) and between individuals to be investigated. Nanofluidic devices have emerged as powerful tools for handling and analyzing single DNA molecules. DNA stretching in nanofluidics has been applied to repressor binding, ${ }^{1}$ restriction mapping ${ }^{2}$ and recently, denaturation mapping ${ }^{3}$ and barcoding ${ }^{4}$ of viral DNA or BACs of limited length (100-400 $\mathrm{kbp}$ ). However, if the size of the DNA that can be handled could extend beyond the megabase scale then individual haplotypes and much of the structural variation in genomes would become accessible. ${ }^{5}$ However, extracting mega base-pair long DNA from realworld samples is a major challenge as single molecules of such lengths are known to be sheared during micropipetting. Given that a microfluidic device has been used for manipulating single chromosomes, ${ }^{6}$ we hypothesized that the metaphase chromosome could act as a robust packaging for delivering DNA that would mitigate against

${ }^{a}$ DTU Nanotech, Oersted Plads, Building 345 east, Technical University of Denmark, DK-2800 Kongens Lyngby, Denmark. E-mail: Rodolphe. Marie@nanotech.dtu.dk; Fax: +45 4588 7762; Tel: +45 45255700

${ }^{b}$ The Wellcome Trust Centre for Human Genetics, Oxford University, Roosevelt Drive, Oxford, OX3 7BN, UK. E-mail: kalim@well.ox.ac.uk; Fax: +44 (0)1865 287501; Tel: +44 (0)1865287500

$\uparrow$ Electronic supplementary information (ESI) available: Fig. S1: COMSOL simulations of the diffusion of protease inside the trap area Fig. S2: movie showing DNA stretched by introduction to the nanoslit. See DOI: $10.1039 / \mathrm{c} 0 \mathrm{lc} 00603 \mathrm{c}$ the shearing effects of pipetting (Fig. 1B). In this paper we report the design, fabrication and use of a device (Fig. 1A) for handling and extracting DNA from metaphase chromosomes. The device design aims to immobilize a single metaphase chromosome in an isolation zone (Fig. 1C) through which reagents can be exchanged by diffusion (Fig. 1D) enabling proteins to be digested. The DNA thus extracted can then be shunted out of the isolation zone into a nanoslit for stretching (Fig. 1E).

The device was designed, with the aid of finite element simulations (COMSOL, USA; see Fig. S1, ESI $\dagger$ ), to have a series of isolation zones to slow down the chromosomes in the trap area while maintaining a high flow rate through the device. The parallel isolation zones increased in area with increasing distance $\left(3000 \mu \mathrm{m}^{2}, 6000 \mu \mathrm{m}^{2}\right.$, $9000 \mu \mathrm{m}^{2}$, etc.) from the sample entry point, in order to obtain a homogeneous flow rate into each of the zones during the introduction of the sample. This was to ensure that all chromosomes

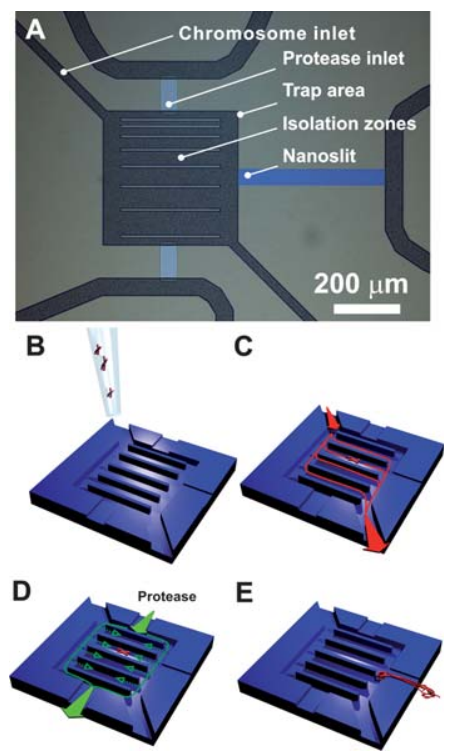

Fig. 1 (A) Optical image of the sealed device showing the trap area with access microchannels. (B) A metaphase chromosome-enriched cell extract is loaded into the device and $(\mathrm{C})$ flushed through the trap area where single chromosomes can be observed in an isolation zone. (D) Protease is introduced in the device without displacing the chromosome of interest and (E) released DNA is pushed into a $100 \mathrm{~nm}$ high nanoslit. 


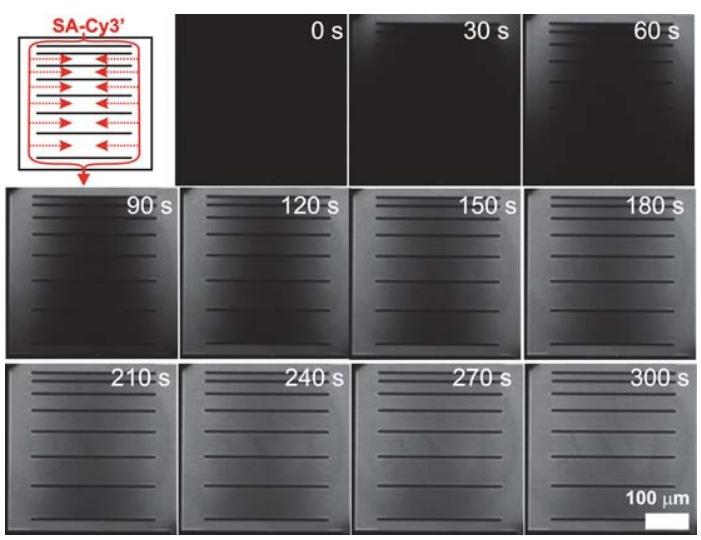

Fig. 2 Experimental time-lapse imaging of the increasing fluorescence in the trap area due to the diffusion of stretavidin-Cy3 as it is injected at $0.6 \mathrm{~nL} \mathrm{~min}{ }^{-1}$. The diffusion constant is $60 \times 10^{-12} \mathrm{~m}^{2} \mathrm{~s}^{-1}$.

entering isolation zones were moving at the same horizontal speed in order to facilitate selection of individual chromosomes from the parade of chromosomes and cell debris flowing through the device.

The device was fabricated using UV lithography and reactive ion etching of a silicon substrate. Briefly, a $500 \mathrm{~nm}$ dry thermal oxide was grown on a silicon wafer. The protease inlet slit and the slit for DNA stretching were defined by UV masking and deep reactive ion etching in the oxide at the depth of $500 \mathrm{~nm}$ and $100 \mathrm{~nm}$ respectively. The $50 \mu \mathrm{m}$ wide microfluidic channels connecting the inlet ports and the $400 \times$ $400 \mu \mathrm{m}$ trap area were defined using a third UV lithography step and were etched in silicon at a depth of $10 \mu \mathrm{m}$. A thermal oxide was grown in order to later allow fusion bonding. Inlet holes were made by powder blasting from the backside of the device which was finally sealed by fusion bonding to a $500 \mu \mathrm{m}$ thick borofloat glass wafer. The protease reagent was introduced from the top of the device with flow occurring perpendicular to the isolation zones. In this configuration there was no flow into the isolation zones; reagent exchange with the stagnant volume inside the zones occurred by diffusion only.

We used streptavidin labelled with Cy3 to visualize the diffusion of the reagent into the isolation zones to verify device operation before chromosome isolation and protease digestion was conducted. Observation of the introduction and spread of the $\mathrm{Cy} 3$ fluorescent marker into the isolation zones (Fig. 2) validated the device design and indicated that the reagent is able to spread quite well throughout the isolation zones by time, $300 \mathrm{~s}$.

The device and reagent exchange process was then applied to a sample containing metaphase chromosomes. The chromosomes were isolated from Jurkat cells (DSMZ, Germany: ACC282) in a polyamine buffer as described by Cram et al. ${ }^{7}$ with some modifications. Briefly, the Jurkat cells were grown at $37{ }^{\circ} \mathrm{C}$ in a $5 \% \mathrm{CO}_{2}$ atmosphere. At exponential growth, they were arrested in metaphase with colcemide at $0.06 \mu \mathrm{g} \mathrm{mL} \mathrm{m}^{-1}$ for $12-16$ hours. The cells were collected at $200 \mathrm{~g}$ for 10 minutes and re-suspended in a swelling buffer (55 mM NaNO $3,55 \mathrm{mM} \mathrm{CH}_{3} \mathrm{COONa}, 55 \mathrm{mM} \mathrm{KCl}, 0.5 \mathrm{mM}$ spermidine, $0.2 \mathrm{mM}$ spermine) at approximately $10^{6}$ cells per $\mathrm{mL}$ and incubated for 45 minutes at $37^{\circ} \mathrm{C}$. The swollen cells were collected at $200 \mathrm{~g}$ for 10 minutes and re-suspended in an ice-cold isolation buffer: at approximately $8 \times 10^{6}$ cells per $\mathrm{mL}$. The cells were lysed by vigorous vortex for $30 \mathrm{~s}$. The chromosome content was estimated to be in the order of $10^{7}$ cells per mL. The device was mounted on a holder interfacing the inlet holes of the device with pressured air allowing movement of the solution inside the device as described elsewhere. ${ }^{8}$ Fluorescence imaging was performed using an inverted microscope (Nikon Eclipse TE2000, Japan) equipped with a $60 \times 1$ 1.00 water immersion objective and an EMCCD camera (Photometrics Cascade II512, USA). The temperature inside the device was controlled by a cartridge heater held in contact with the backside of the silicon device. Inlet holes were loaded with $30 \mu \mathrm{L}$ of solution unless otherwise mentioned. Prior to receiving the chromosomes, the device was flushed by $1 \%$ sodium dodecyl sulfate, buffer solution $\S$ and BSA at $1 \mathrm{mg} \mathrm{mL}^{-1}$ for 10 minutes. 1000-2000 chromosomes were added to the diagonal inlet port (Fig. 1B); the depth of the microfluidic structure allowed the cell extract to be flushed quickly through the isolation zone while watching for the appearance of chromosomes that could be isolated (Fig. 1C). A single chromosome was trapped in an isolation zone of the device (as illustrated in Fig. 1C). Simultaneously the temperature was adjusted to $37^{\circ} \mathrm{C}$ and a $100 \mu \mathrm{g} \mathrm{mL}^{-1}$ solution of protease $\mathrm{K} \Phi$ was introduced (Fig. 1D). The device enabled a high flow rate of $0.6 \mathrm{~nL} \mathrm{~min}^{-1}$ allowing the protease to diffuse quickly into the stagnant volume within the isolation zone.

Moreover, a continuous flow through the device ensured that after 4 minutes the protease concentration around the isolated chromosome was maintained above $50 \mu \mathrm{g} \mathrm{mL} \mathrm{mL}^{-1}$ (Fig. S1† and Fig. 2) and that the digestion products were washed away from the isolation zone
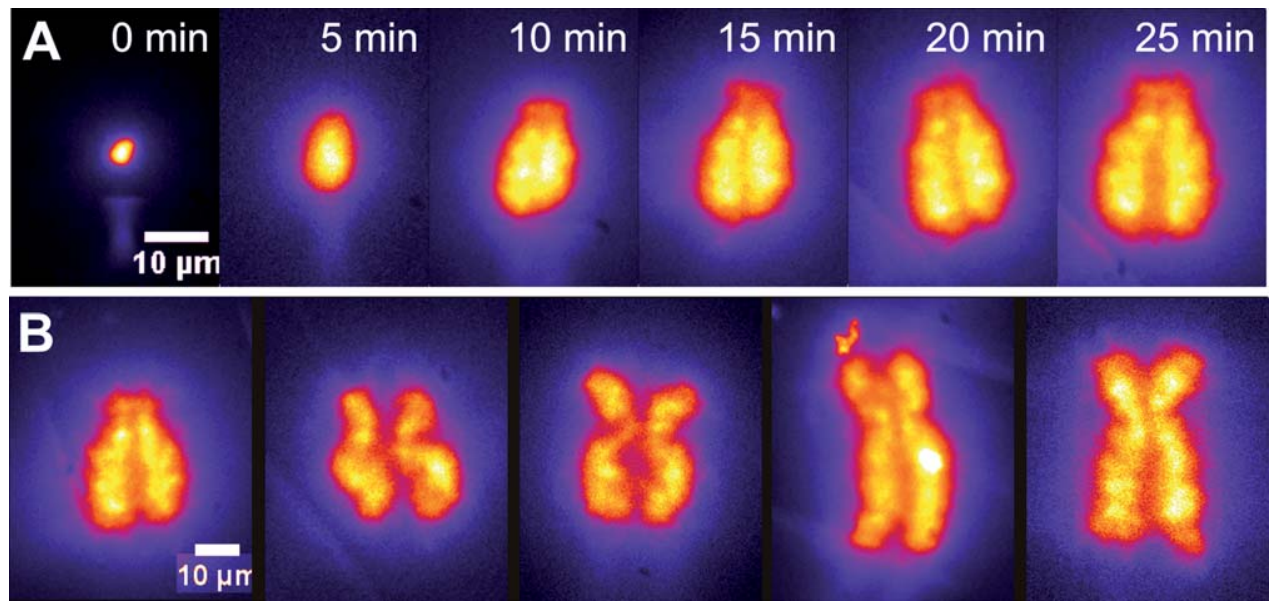

Fig. 3 (A) Time-lapse image series of a single metaphase chromosome during digestion with protease at $37{ }^{\circ} \mathrm{C}$. (B) A panel of different individually isolated chromosomes after 40 minutes digestion. 


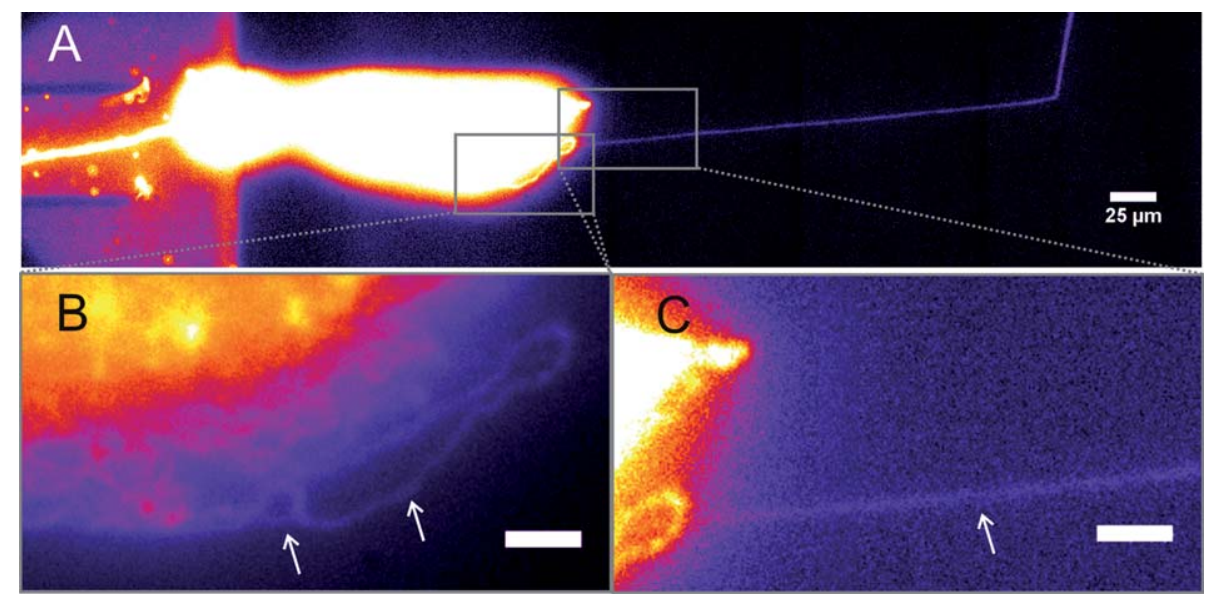

Fig. 4 (A) After completion of the digestion DNA released from an individual chromosome is passed through a $100 \mathrm{~nm}$ high slit; a long strand is seen to emerge (B) close-up of loops of DNA emanating from the core package of DNA. (C) Close-up of the linear DNA strand emerging from the DNA package.

through diffusion. As proteolysis took place, the chromosome swelled (Fig. 3A) and self-aligned in the plane of the device allowing reliable and reproducible fluorescence time-lapse imaging. Although no visible change of the chromosome was observed after $t=25$ minutes, digestion was allowed to proceed for one hour as recommended by protocols for digestion in bulk solution. ${ }^{9}$ It is striking that even after a digestion treatment that should be sufficient to remove all proteins, sister chromatids could still be clearly identified and chromosomes of different sizes and with different centromere positions could be seen (Fig. 3B). Moreover heterogeneity in the chromatin folding morphology could be observed at the micrometre scale.

The chromosomal DNA could be easily manipulated by using the sample inlet/outlet microchannels and the reagent inlet/outlet slits as a bi-directional flow system inside the trap area. This enabled the chromosomal DNA to be moved in front of $100 \mathrm{~nm}$ high slit and then forced in (Fig. S2, ESI $\dagger$ ). Although, the bi-directional flow in the trap area would enable DNA extracted from chromosomes trapped in different isolation zones to each be individually manipulated and moved toward the slit, the present study has worked with a dilute solution of chromosomes and so only one chromosome at a time was processed. The post-digestion chromosomal DNA was observed as a densely packed core composed of separated loops (Fig. 4). The chromosomal DNA was highly pliable: the DNA stretched by increasing the flow through the nanoslit and recoiled when the flow was stopped as in Fig. 4A. Loops of DNA were seen to escape from the main core of the chromosomal DNA (Fig. 4B) and a longer separate strand stretched across the whole length of the $450 \mu \mathrm{m}$ long nanoslit and out into a microchannel (Fig. 4C). This corresponded to a minimal length of $\sim 1.3 \mathrm{Mbp}$ (1.3 million bases) of fully elongated DNA. Such separated DNA strands were also visible around the chromosomal DNA before the introduction to the nanoslit (see last frames of Fig. S2 $\dagger$ ).

In summary, we designed a silicon device able to trap a particle and to exchange reagent over the particle without dislodging it from its site of isolation. We applied the device to the trapping of single metaphase chromosomes and were able to digest chromosomal proteins to obtain a DNA package that retained a loose two-chromatid structure. The DNA package could be fluidically manipulated and was forced into a nanoslit where a single linear strand was elongated out. The stretching out of DNA from individual chromosomes will be important for mapping the linear organisation of sequence along the molecule which is essential for obtaining ultralong range haplotype and genome structural information. It is expected that the ability to visualize the unravelling of chromatin and extraction of DNA will enable studies into the organisation and topology of chromatin in mitotic chromosomes. The device architecture, which contains isolation zones of various sizes, will provide flexibility for analysing other biological samples that may be of interest such as large macromolecular complexes and individual cells.

\section{Acknowledgements}

The research leading to these results has received funding from the European Union's Seventh Framework Programme (FP7/20072013) under grant agreement no 201418 (READNA) and from the Danish research council for technology and production under grant number (274-06-0237). We thank David Bauer for comments on the manuscript.

\section{Notes and references}

\$ $15 \mathrm{mM}$ Tris- $\mathrm{HCl}, 2 \mathrm{mM}$ EDTA, $80 \mathrm{mM} \mathrm{KCl}, 20 \mathrm{mM} \mathrm{NaCl}, 0.5 \mathrm{mM}$ EGTA, $0.5 \mathrm{mM}$ spermidine, $0.2 \mathrm{mM}$ spermine, $0.12 \%$ digitonin, and $7 \mathrm{mM}$ mercaptoethanol.

$\S 0.5 \times$ TBE, $3 \% \beta$-mercaptoethanol (BME) and $0.5 \%$ Triton X-100.

I $1 \mu \mathrm{M}$ of YOYO- 1 is added to the protease $\mathrm{K}$ solution for staining the DNA strands while cut free from the chromatin in the vicinity of the bright chromosome body.

1 Y. M. Wang, J. O. Tegenfeldt, W. Reisner, R. Riehn, X.-J. Guan, L. Guo, I. Golding, E. C. Cox, J. Sturm and R. H. Austin, Proc. Natl. Acad. Sci. U. S. A., 2005, 102, 9796-9801.

2 R. Riehn, M. Lu, Y.-M. Wang, S. F. Lim, E. C. Cox and R. H. Austin, Proc. Natl. Acad. Sci. U. S. A., 2005, 102, 10012-10016.

$3 \mathrm{~W}$. Reisner, N. B. Larsen, A. Silahtaroglu, A. Kristensen, N. Tommerup, J. O. Tegenfeldt and H. Flyvbjerg, Proc. Natl. Acad. Sci. U. S. A., 2010, 107, 13294.

4 S. K. Das, M. D. Austin, M. C. Akana, P. Deshpande, H. Cao and M. Xiao, Recent Dev. Nucleic Acids Res., 2010, 38(18).

5 K. U. Mir, Briefings Funct. Genomics Proteomics, 2009, 8, 367-378.

6 T. Inoue, K. Takahashi and H. Yokoyama, Arch. Histol. Cytol., 2002, 65, 465-471.

7 L. S. Cram, C. S. Bell and J. J. Fawcett, Methods Cell Sci., 2002, 24, 27-35.

8 W. Reisner, N. B. Larsen, H. Flyvbjerg, J. O. Tegenfeldt and A. Kristensen, Proc. Natl. Acad. Sci. U. S. A., 2009, 106, 79-84.

9 J. Sambrook, E. F. Fritsch and T. Maniatis, Molecular Cloning: a Laboratory Manual, Cold Spring Harbor Laboratory, 1989. 